\title{
Application of different nitrogen doses in fertirrigated cacao seedlings
}

\author{
Aplicação de diferentes doses de nitrogênio em mudas de cacaueiro fertirrigadas \\ Aplicación de diferentes dosis de nitrógeno en plántulas de cacao fertirrigadas
}

Received: 08/13/2021 | Reviewed: 08/19/2021 | Accept: 08/24/2021 | Published: 08/25/2021

\author{
Matheus Hofmann Trevisan \\ ORCID: https://orcid.org/0000-0001-7398-5654 \\ Universidade Federal do Pará, Brazil \\ E-mail: mateustrevis@hotmail.com \\ Sandra Andrea Santos da Silva \\ ORCID: https://orcid.org/0000-0002-1742-1544 \\ Universidade Federal do Pará, Brazil \\ E-mail: sandrasilva@ufpa.br \\ Maysa Lorrane Medeiros de Araújo \\ ORCID: https://orcid.org/0000-0002-9307-3166 \\ Universidade Federal do Pará, Brazil \\ E-mail: maysamedeiros97@gmail.com \\ Vivian Dielly da Silva Farias \\ ORCID: https://orcid.org/0000-0003-0395-7839 \\ Universidade Federal do Pará, Brazil \\ E-mail: vivianfarias@ufpa.br \\ Miguel Alves Júnior \\ ORCID: https://orcid.org/0000-0002-2416-6668 \\ Universidade Federal do Pará, Brazi \\ E-mail: agrovida.jr@gmail.com \\ Cláudia Barbosa Cordeiro \\ ORCID: https://orcid.org/0000-0001-9554-004X \\ Universidade Federal do Pará, Brazil \\ E-mail: clauagro97@gmail.com \\ Vitor Lunelli Araújo \\ ORCID: https://orcid.org/0000-0003-4529-4789 \\ Universidade Federal do Pará, Brazi \\ E-mail: vitorlunellilpj@gmail.com \\ Emanuelle Valeska Bilhar Araújo \\ ORCID: https://orcid.org/0000-0001-9654-4595 \\ Universidade Federal do Pará, Brazil \\ E-mail: emanubilhar@gmail.com \\ Rafael Oliveira da Silva \\ ORCID: https://orcid.org/0000-0002-4728-2493 \\ Universidade Federal do Pará, Brazil \\ E-mail: rafaelosilva21@gmail.com
}

\begin{abstract}
The Medicilândia municipality is the main dried cocoa beans producer in Pará state, however, researches are being carried out in relation to the seedlings production. The study objective was to study the cacao seminal seedlings growth under a drip irrigation system, receiving different nitrogen doses with fixed doses of phosphorus $(4,5 \mathrm{~g})$ and potassium $(3 \mathrm{~g})$ through fertirrigation. The experiment was realized under greenhouse conditions with four treatments and five repetitions in a design of randomized blocks, being each composed by seven plants. Thus, $\mathrm{T} 1=$ check, without fertilization; $\mathrm{T} 2=2 \mathrm{~g}$ of $\mathrm{N}+\mathrm{P}$ and $\mathrm{K} ; \mathrm{T} 3=7 \mathrm{~g}$ of $\mathrm{N}+\mathrm{P}$ and $\mathrm{K} ; \mathrm{T} 4=12 \mathrm{~g}$ of $\mathrm{N}+\mathrm{P}$ and $\mathrm{K}$. The treatments were scientific from the 31st to the 156th day after sowing, where the values of height, collar diameter and leaves number were obtained fortnightly. On the 156th day, the plants were harvested and obtained the root length, fresh matter and aerial part dry matter and root and the nutritional contents from the leaf and root plant tissue. The plants obtain results with the highest values of height, collar diameter and leaves number in the T2 treatment.
\end{abstract}

Keywords: Fertilization; Irrigation; Theobroma cacao L.; Plants nutrition.

\section{Resumo}

O município de Medicilândia é o principal produtor de amêndoas secas de cacau no estado do Pará, no entanto, poucas pesquisas são desenvolvidas com relação a produção de mudas. O objetivo deste trabalho foi estudar o crescimento de mudas seminais de cacaueiro sob sistema de irrigação por gotejamento, recebendo diferentes doses de nitrogênio com doses fixas de fósforo $(4,5 \mathrm{~g})$ e potássio $(3 \mathrm{~g})$ através de fertirrigação. O experimento foi realizado em 
condições de ambiente protegido com quatro tratamentos e cinco repetições em um delineamento de blocos casualisados, sendo cada repetição composta por sete plantas. Dessa forma, T1= testemunha, sem adubação; T2 = $2 \mathrm{~g}$ de $\mathrm{N}+\mathrm{P}$ e K; T3 = $7 \mathrm{~g}$ de $\mathrm{N}+\mathrm{P}$ e K; T4 = $12 \mathrm{~g}$ de N + P e K. Os tratamentos foram aplicados do $31^{\circ}$ ao $156^{\circ}$ dia após a semeadura, onde foram avaliados quinzenalmente os valores de altura, diâmetro do coleto e número de folhas. No $156^{\circ}$ dia as plantas foram colhidas e avaliados o comprimento da raiz, matéria fresca e matéria seca da parte aérea e radicular e os teores nutricionais do tecido vegetal foliar e radicular. As plantas responderam aos tratamentos apresentando maiores valores de altura, diâmetro do coleto e número de folhas no tratamento T2.

Palavras-chave: Adubação; Irrigação; Theobroma cacao L.; Nutrição de plantas.

\section{Resumen}

El municipio de Medicilândia es el principal productor de almendras sequías del cacao en el estado de Pará, sin embargo, se realizan pocas investigaciones sobre la producción de plántulas. El objetivo de este trabajo fue estudiar el crecimiento de plántulas seminales de cacao bajo un sistema de riego por goteo, recibiendo diferentes dosis de nitrógeno con dosis fijas de fósforo $(4,5 \mathrm{~g})$ y potasio $(3 \mathrm{~g})$ mediante fertirrigación. El experimento se llevó a cabo en condiciones de invernadero con cuatro tratamientos y cinco réplicas en un diseño de bloques al azar, con cada réplica compuesta por siete plantas. Así, T1 = control, sin fertilización; T2 = 2 g de N + P y K; T3 = 7 g de N + P y K; T4 = $12 \mathrm{~g}$ de N + P y K. Los tratamientos se aplican desde el día 31 hasta el 156 después de la siembra, donde se evaluaron los valores de altura, diámetro del tallo y número de hojas cada dos semanas. En el día 156, tal como se cosecharon, se valoraron las plantas o compresión de raíces, materia fresca y materia seca de brotes y raíces y la teoría nutricional del tejido foliar y raíz de la planta. Las plantas responden a tratamientos con mayores valores de altura, diámetro de tallo y número de hojas en el tratamiento T2.

Palabras clave: Fertilizantes; Irrigación; Theobroma cacao L.; Nutrición vegetal.

\section{Introduction}

The Medicilândia municipality, located in the Transamazônica region, Pará state, is known by its high potential in the dried cocoa beans production for chocolate and cocoa butter manufacture. According to the Geography and Statistics Brazilian Institute (IBGE, 2019) the dried cocoa beans average production in the county in 2019 was around 44.738 tons, equivalent to more than $34 \%$ from paraense production.

Cocoa is typical of tropical climate and, therefore, very demanding in water, the crop demands high rainfall with about $1.200 \mathrm{~mm}$ per year, distributed in $100 \mathrm{~mm}$ Monthly (Souza et al., 2009).

Regarding to cocoa mineral nutrition, it is known that the requirement for nitrogen $(\mathrm{N})$ and potassium $(\mathrm{K})$ is high in the fruiting phase and contributes to the production increase, nevertheless, there are few studies in the seedlings production phase (Sodré et al. 2012; Almeida et al. 2014). In addition, for the cacao effective fertilization, the water correct management so that the nutrients are solubilized, since most part of these nutrients are absorbed through mass flow. At the same time, it is common leaching losses, causing damage to the environment and production costs increase (Silva et al., 2017).

The fertirrigation seeks to unify the benefits of water supply and nutrients supply to crops, with the purpose of reducing labor costs and enabling the fertilizers use in irrigated agriculture, as it increases the efficiency of its use (Coelho et al., 2010). This technique basically consists in the combined fertilizers usage with the irrigation process, in this way the manures are injected into the water forming what it is called "enriched irrigation water".

Thus, this work aimed to evaluate the cacao seminal seedlings growth under irrigation system located by drip, receiving different nitrogen doses with fixed phosphorus and potassium dosages through fertirrigation.

\section{Methodology}

The experiment was conducted from April 25th to September 28th 2019 at Alvorada Farm, located at Km 80 South of the Transamazônica highway (BR-230) towards Altamira-Itaituba, under coordinates 3²7'11" S and 52 '48'17” W and 270 meters of altitude (Figure 1). 
Figure 1: Location of the experiment deployment property.

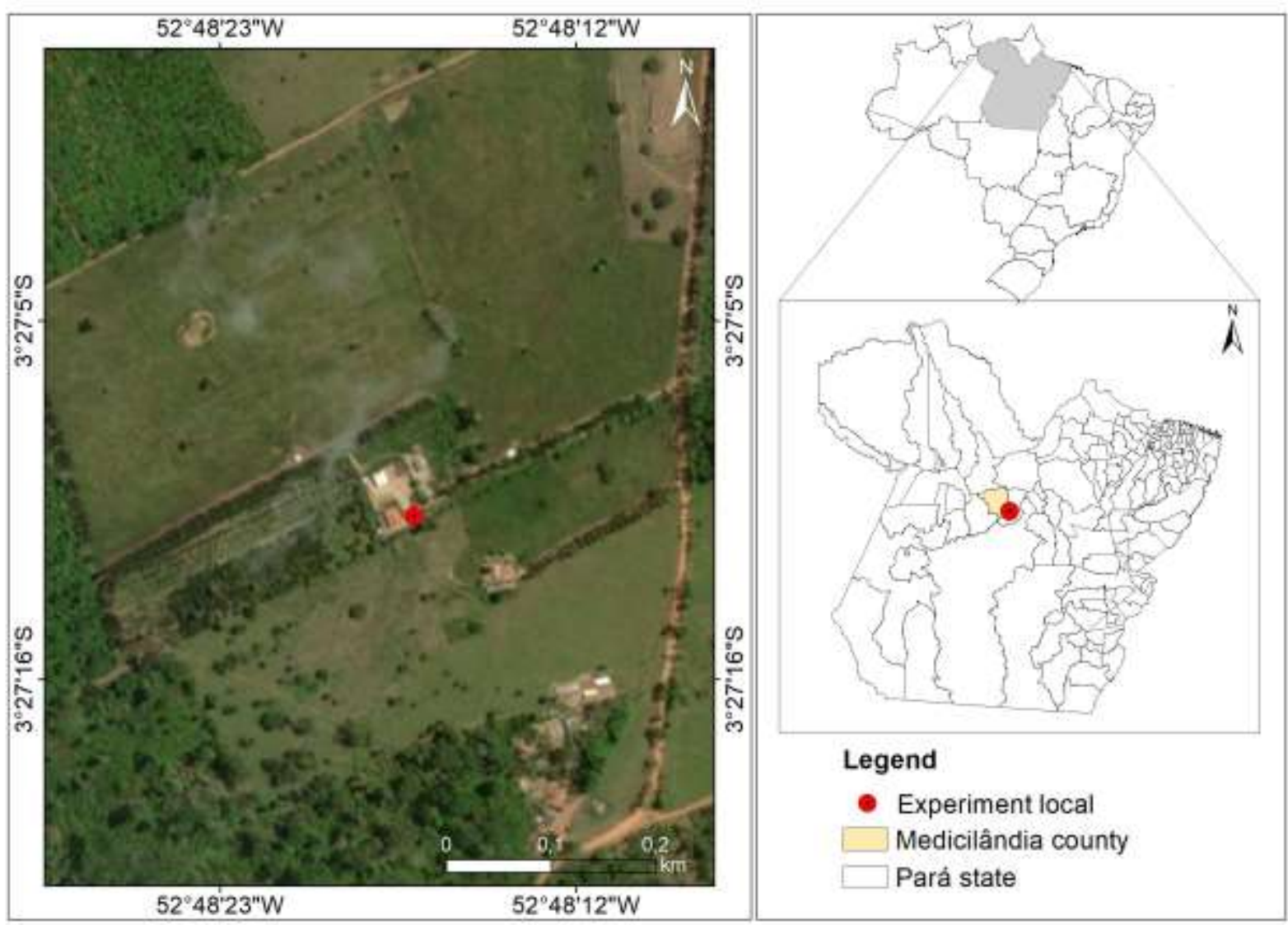

Source: Authors.

The region presents humid tropical climate, with dry season, Am type, characterized by average annual precipitation above $1.500 \mathrm{~mm}$ and average temperature above $18^{\circ} \mathrm{C}$ in the coldest month of the year (Koppen, 1936).

It was assembled a greenhouse type nursery $8 \times 11 \mathrm{~m}$ and covered with agrofilm (200 microns) and and a shading screen (50\%). For the irrigation system, it was measured the flow of 2 random drippers for each of the 6 lateral lines, checking the collected water volume in 10 minutes. It was found that the average flow of each individual dripper individually corresponds to $0,172 \mathrm{~L} / \mathrm{h}$ and for the whole system it corresponds to $41,28 \mathrm{~L} / \mathrm{h}$, including the edges, with C.V. $=9,45 \%$. The average operating pressure for the entire system was 2 mca.

At the beginning of each lateral line, it was placed a register that allowed the individual opening during the nutritional solution application, which it was prepared from the granulated fertilizer grinding and dissolved in water. The fertilizer injection into the system was done through the Venturi tube method in an easel. The daily water blade applied was equivalent to the local average daily potential evapotranspiration (ETo) for the referred month in which the experiment was located. For sowing and fertilizer applications the soil was raised to field capacity. The used seeds for the seedlings production were taken from a single adult plant (matrix) in fructification phase, which were germinated in sawdust until transplanted into plastic bags of $2,2 \mathrm{dm}^{3}$.

The seedlings were conducted only with irrigation up to 30 days. The experimental design was in randomized blocks with four treatments and five blocks (repetitions). The treatments differ by the applied $\mathrm{N}$ doses, keeping phosphorus and potassium constant at the doses of 4,5 $\mathrm{g}$ of $\mathrm{P}$ and $3 \mathrm{~g}$ of $\mathrm{K}$. Thus, $\mathrm{T} 1=$ check, without fertilization; $\mathrm{T} 2=2 \mathrm{~g}$ of N $+\mathrm{P}$ and $\mathrm{K} ; \mathrm{T} 3$ $=7 \mathrm{~g}$ of $\mathrm{N}+\mathrm{P}$ and $\mathrm{K} ; \mathrm{T} 4=12 \mathrm{~g}$ of N $+\mathrm{P}$ and $\mathrm{K}$. The nutrients doses correspond to $10 \%, 5 \%$ and $10 \%$ of the recommended 
elements for the culture's first year, N, P and K, respectively, according to the used soil characteristics (EMBRAPA, 2007).

The seedlings were daily irrigated and the nutritional solution applications occurred weekly, being the apportioned doses so that they reached the defined value for each treatment at the end of the experiment. The used elements sources were urea, triple superphosphate and potassium chloride. The values of each repetition are an arithmetic average of 7 plants. The area representative sketch is illustrated in Figure 2.

Figure 2: Experimental area sketch.

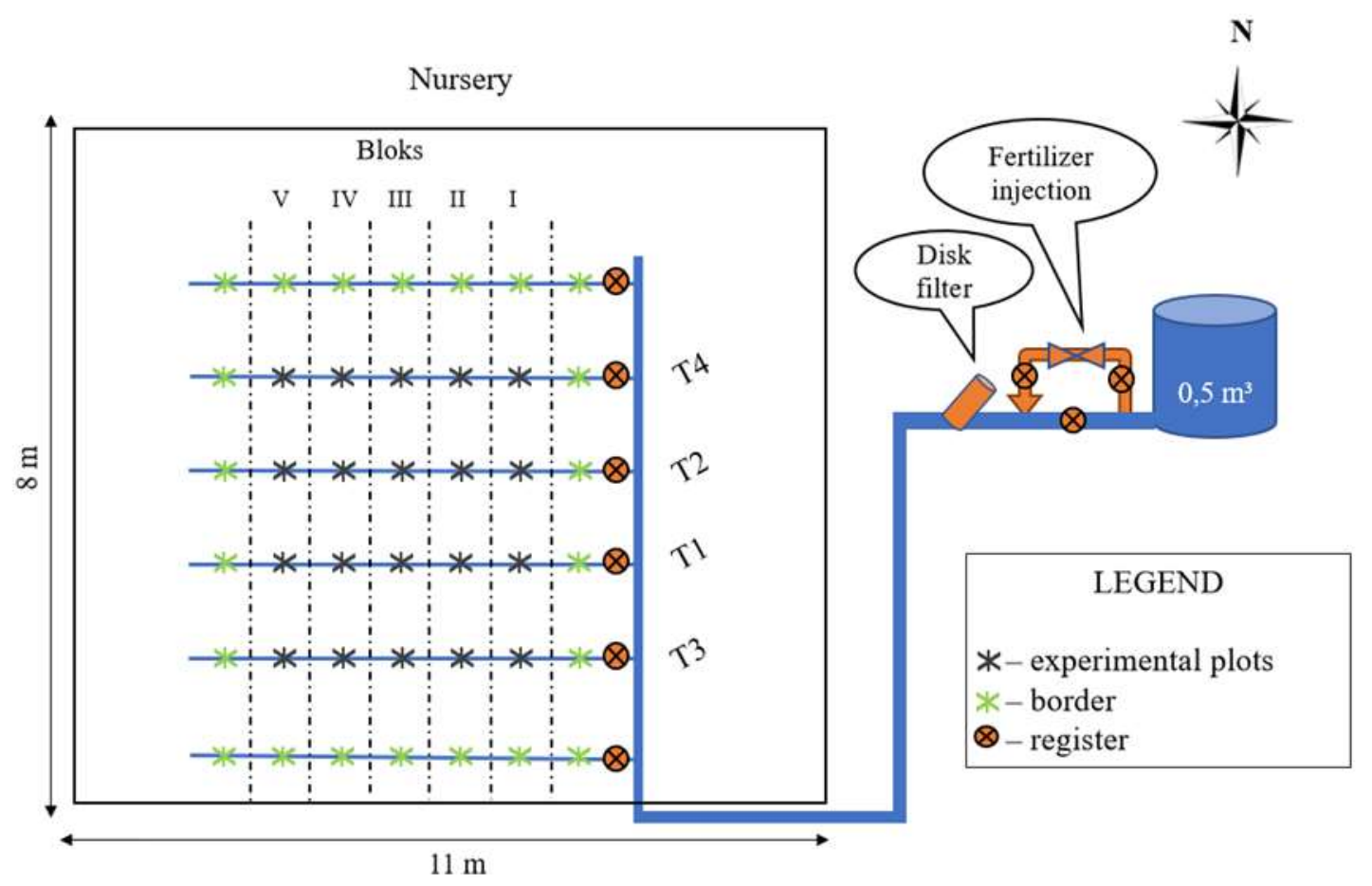

Source: Authors.

The evaluated parameters were: plants height; collar diameter; leaves number; root system length; root green matter weight and from the aerial part; root dry matter weight and from the aerial part; chemical analysis (macro and micronutrients) from the leaf and root plant tissue.

The data analyses were performed through the statistical analysis software Sisvar 5.6 being the results compared by the Scott-Knott test (1974) at 5\% error probability. The doses influence levels in the treatments were compared through regression analysis.

\section{Results and Discussion}

\subsection{Height}

Through the average comparisons analysis by Scott-Knott (1974) (Table 4), the treatments T1 and T2 presented higher average height in relation to the other higher at 58 and 72 days of age. At 86 days, the corresponding dose to the T2 treatment provided greater height. At 156 days of age, the plants from treatment $\mathrm{T} 2$ were the ones that presented the highest height values, with an average of $60,28 \mathrm{~cm}$, while the plants from treatment T4 presented the lowest values, with an average of $44,62 \mathrm{~cm}$. 
Table 1: Height average values of cacao seedlings in different age days under different $\mathrm{N}$ doses $(\mathrm{cm})$.

\begin{tabular}{|c|c|c|c|c|c|c|c|c|c|}
\hline \multirow[t]{2}{*}{ Doses (g) } & \multicolumn{9}{|c|}{ Days } \\
\hline & 44 & 58 & 72 & 86 & 100 & 114 & 128 & 142 & 156 \\
\hline $\mathbf{0}$ & $18,18 \mathrm{a}$ & $20,22 a$ & $24,00 \mathrm{a}$ & $27,12 b$ & $32,36 a$ & $35,82 a$ & $41,56 a$ & $46,98 \mathrm{a}$ & $52,86 b$ \\
\hline 2 & $18,32 \mathrm{a}$ & $20,98 \mathrm{a}$ & $24,62 \mathrm{a}$ & $29,40 \mathrm{a}$ & $35,08 \mathrm{a}$ & $39,44 a$ & $45,74 a$ & $51,58 \mathrm{a}$ & $60,28 \mathrm{a}$ \\
\hline 7 & $18,10 \mathrm{a}$ & $19,68 b$ & $22,84 b$ & $26,04 b$ & $31,18 \mathrm{a}$ & $35,06 a$ & $40,74 a$ & $44,60 \mathrm{a}$ & $50,44 b$ \\
\hline 12 & $17,88 \mathrm{a}$ & $19,12 b$ & $21,82 b$ & $24,36 b$ & $29,26 a$ & $31,86 a$ & $36,76 a$ & $41,68 \mathrm{a}$ & $44,62 \mathrm{c}$ \\
\hline
\end{tabular}

Followed values by equal letters in the same column do not differ with each other at $\mathrm{p}<0.05$ by the Scott-Knott test (1974). Source: Authors.

It was observed in this research a faster development in the cacao seedlings height than those found by Santos (2019), for seedlings with the same age. The obtained values for height in this work are also considerably superiors than those found by Souza Júnior and Carmello (2008), who observed the cocoa clonal seedlings behavior under different urea doses, where they reached a maximum height of $14,86 \mathrm{~cm}$ with application via substrate and $13,33 \mathrm{~cm}$ via leaf. It is noteworthy that the It is noteworthy that the worked doses by the referred authors were lower than those used in this research. In Figure 3, it is possible to notice the visual difference between the treatments.

Figure 3: Treatments visual analysis of $\mathrm{N}$ doses in cacao seedlings at 156 age days.

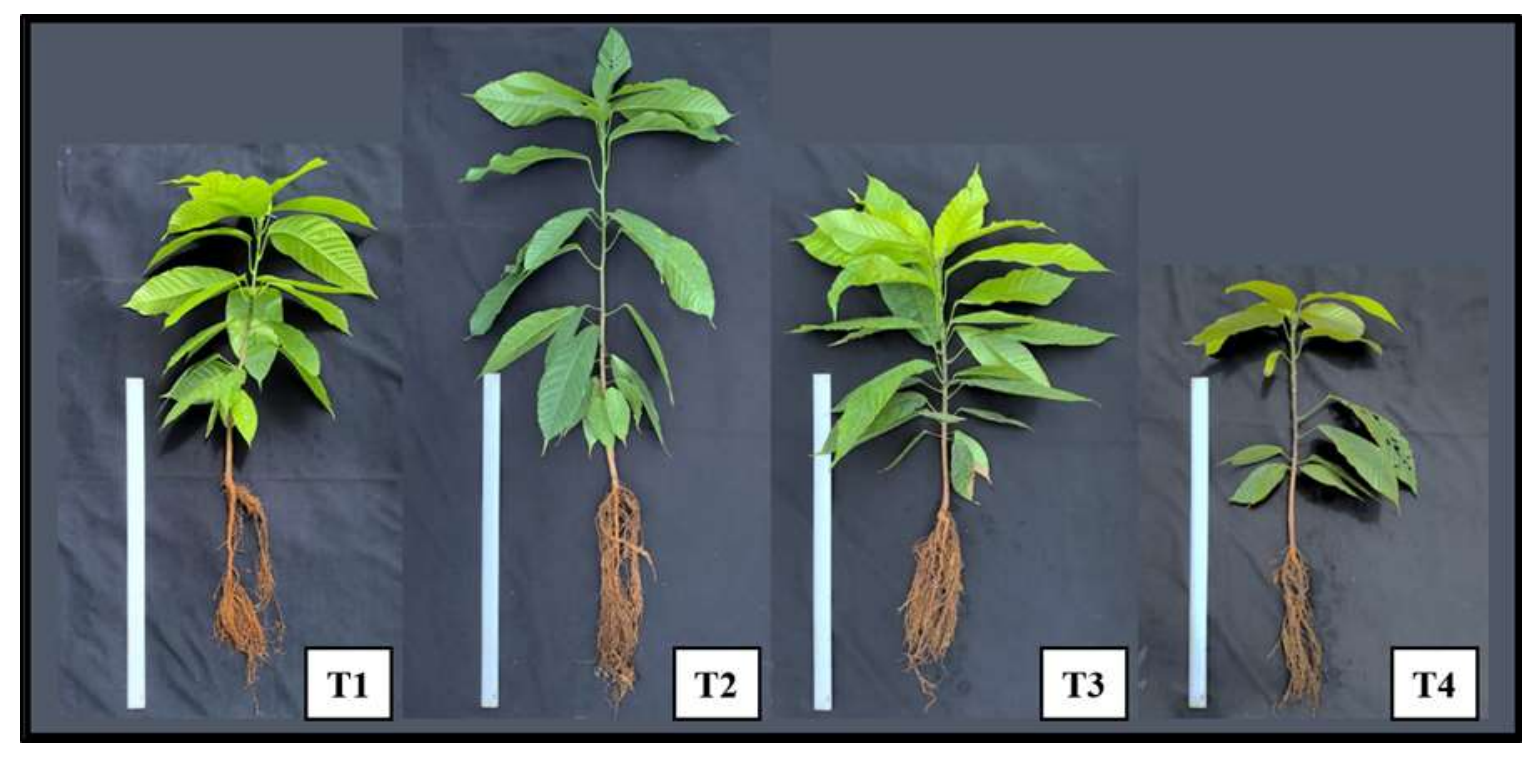

Source: Authors.

The nitrogen has a structural function in the plant, therefore, essential for its vegetative growth. In addition to participating in the plant vital processes such as photosynthesis and respiration, it has an important role in the ionic absorption from the other elements and in the growth and cell differentiation of the plant tissues (Ferreira, 2019).

In Figure 4, it is shown a quadratic regression graphic showing the $\mathrm{N}$ doses influence on plants height at 156 age days. 
Figure 4: Cacao seedlings height at 156 age days in $\mathrm{N}$ doses function.

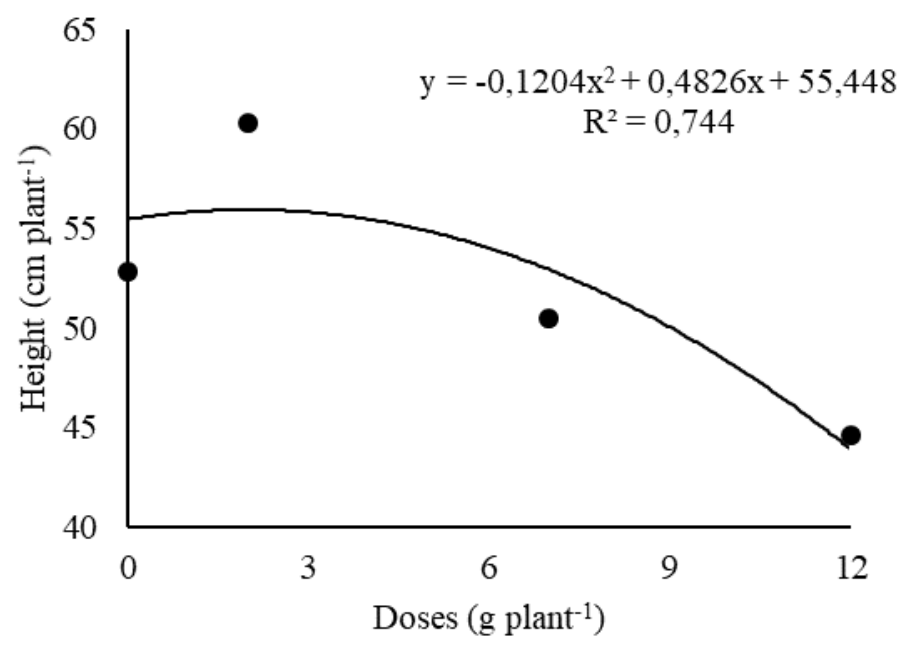

Source: Authors.

The regression model shows an increasing behavior up to the optimal dose of $2 \mathrm{~g}$ per plant, which corresponds to an approximate height of $55,96 \mathrm{~cm}$.

The nitrogen fertilizers excessive usage salines the soil, which can restrict the plants growth, since the mineral ions exceed the nutrient adequate zone, making it difficult the absorption of others or reach levels that come to limit the water availability (Taiz; Zeiger , 2017), a fact that may have contributed to the plants height reduction at higher dosages.

\subsection{Collar diameter}

The average values from the collar diameter are shown in Table 2. It is noticed that the treatments T1 and T2 were the ones that stood out in relation to the others from 86 age days, enduring until the experiment end, where they presented values of $11,13 \mathrm{~mm}$ and $11,46 \mathrm{~mm}$, respectively.

Table 2: Collar diameter average values of cacao seedlings in different age days under different $\mathrm{N}$ doses.

\begin{tabular}{llllllllll}
\hline & \multicolumn{10}{c}{ Days } \\
\cline { 2 - 10 } Doses (g) & 44 & 58 & 72 & 86 & 100 & 114 & 128 & 142 & 156 \\
\hline $\mathbf{0}$ & $3,64 \mathrm{a}$ & $4,42 \mathrm{a}$ & $5,23 \mathrm{a}$ & $5,99 \mathrm{a}$ & $6,75 \mathrm{a}$ & $7,79 \mathrm{a}$ & $8,80 \mathrm{a}$ & $9,88 \mathrm{a}$ & $11,13 \mathrm{a}$ \\
$\mathbf{2}$ & $3,63 \mathrm{a}$ & $4,45 \mathrm{a}$ & $5,29 \mathrm{a}$ & $6,01 \mathrm{a}$ & $6,89 \mathrm{a}$ & $7,96 \mathrm{a}$ & $8,83 \mathrm{a}$ & $10,24 \mathrm{a}$ & $11,46 \mathrm{a}$ \\
$\mathbf{7}$ & $3,64 \mathrm{a}$ & $4,35 \mathrm{a}$ & $4,96 \mathrm{a}$ & $5,56 \mathrm{~b}$ & $6,26 \mathrm{~b}$ & $7,13 \mathrm{~b}$ & $8,05 \mathrm{~b}$ & $8,97 \mathrm{~b}$ & $9,98 \mathrm{~b}$ \\
$\mathbf{1 2}$ & $3,75 \mathrm{a}$ & $4,34 \mathrm{a}$ & $5,00 \mathrm{a}$ & $5,50 \mathrm{~b}$ & $6,14 \mathrm{~b}$ & $6,75 \mathrm{~b}$ & $7,62 \mathrm{~b}$ & $8,57 \mathrm{~b}$ & $9,44 \mathrm{~b}$ \\
\hline
\end{tabular}

Followed values by equal letters in the same column do not differ with each other at $\mathrm{p}<0.05$ by the Scott-Knott test (1974). Source: Authors.

Ferreira (2019) says that it is necessary to establish ideal fertilizer doses for the good development of the seedlings collar diameter, since this is the main indicator from the seedlings survival in the field.

In the Figure 5, it is presented a linear regression graph showing the $\mathrm{N}$ doses influence on the plants collar diameter at 156 age days.

This variable presented a proportional inversely behavior to the $\mathrm{N}$ doses use, differently from what was observed by Souza Júnior and Carmello (2008), who obtained increments, with a fall tendency with higher doses. However, the obtained 
values in this work are similar to those found by Santos (2019) for the same seedlings age, who obtained collar diameter values varying between 6,3 and 7,5 $\mathrm{mm}$ at 120 DAE (days after emergency).

Figure 5: Cacao seedlings collar diameter at 156 age days in $\mathrm{N}$ doses function.

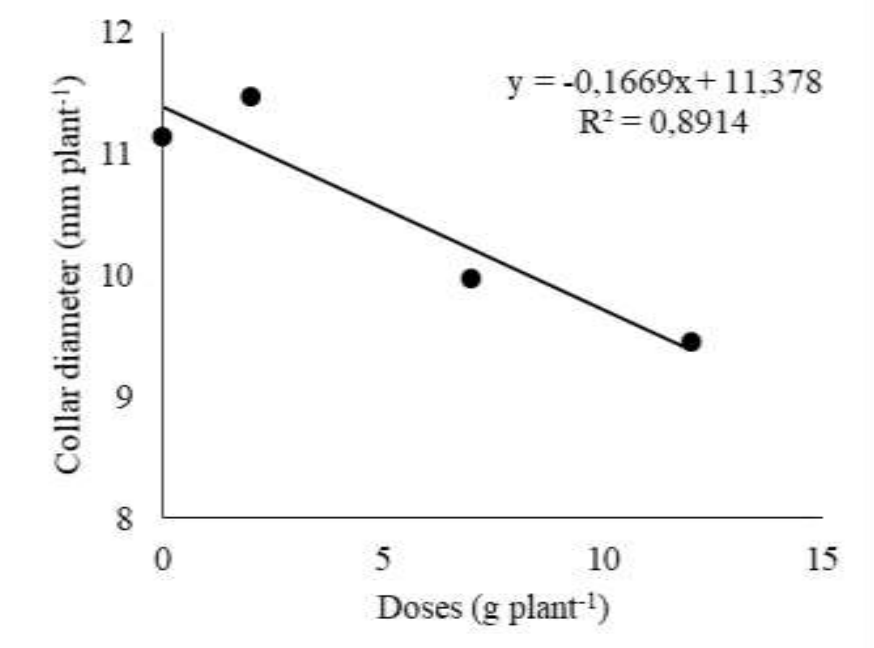

Source: Authors.

Silva et al. (2015) also observed negative effects for the stem diameter variable, in guava rootstocks, attributing this behavior to a nutritional imbalance caused by $\mathrm{N}$ excess or a physiological disorder triggered by the urea excess in the water.

For Gonçalves et al. (2015), within the same species, the plants with higher CD present more chances to survive, as they show formation capacity and of new roots growth.

Increasing $\mathrm{N}$ doses promoted less seedling development in this work, the same was observed by other authors working with fruit species and native species from Amazon (Silva et al., 2015; Bezerra, 2018).

This study is not enough to affirm that nitrogen is the responsible for the deleterious effect caused on cacao seedlings, however this behavior may have been externalized due to the used high amount of this nutrient for the seedling vegetative stage from the studied culture.

\subsection{Leaves number}

In Figure 6, it is shown a quadratic regression graphic where it shows the $\mathrm{N}$ doses influence on the plants leaves number at 156 age days. 
Figure 6: Leaves number in cacao seedlings at 156 age days in $\mathrm{N}$ doses function.

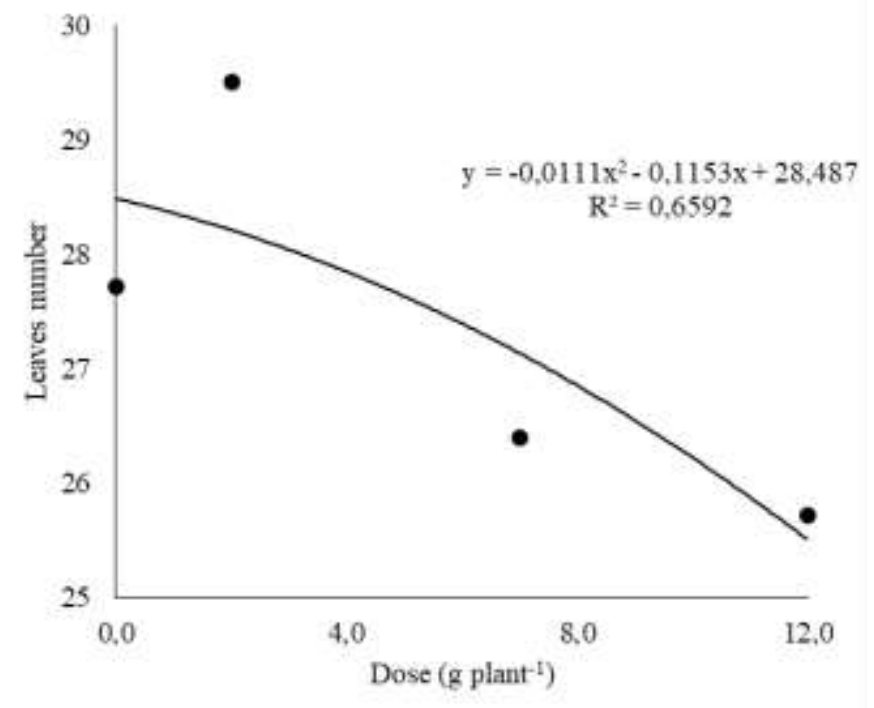

Source: Authors.

Almeida (2014) explains that the nitrogen plays an important role in the metabolism and cocoa plants nutrition, being the foliar component very sensitive to the variation in this nutrient, causing, in cases of deficiency, symptoms such as chlorosis on the leaves (new and old), green pale, reduction in plant size and from the leaves.

Ferreira et al. (2019) explains that this variable, when analyzed separately, is not a good seedlings quality indicator, but when associating them with other variables such as height and dry matter, it can be deduced that seedlings with a greater leaves number represent plants with better nutrition.

Although the treatments did not have statistically deferred from each other in terms of leaves number, higher $\mathrm{N}$ doses provided yellowing followed by burning in some leaves and reduced size. This demonstrates that even though the plant of the same species does not alter its leaves release, the disturbance in the supply of some essential element causes alterations in the crop normal development, resulting in yellowing symptoms and leaf area reduction (Trevisan et al., 2020).

\subsection{Root length, fresh matter and dry matter}

Table 3: Average values of root length (RL), aerial part fresh matter (APFM), root fresh matter (RFM), aerial part dry matter (APDM) and root dry matter (RDM) at 156 age days under different $\mathrm{N}$ doses.

\begin{tabular}{llllll}
\hline Doses $(\mathbf{g})$ & RL $(\mathbf{c m})$ & APFM $(\mathbf{g})$ & RFM $(\mathbf{g})$ & APDM $(\mathbf{g})$ & RDM $(\mathbf{g})$ \\
\hline $\mathbf{0}$ & $48,86 \mathrm{a}$ & $58,23 \mathrm{a}$ & $20,28 \mathrm{a}$ & $19,87 \mathrm{a}$ & $6,28 \mathrm{a}$ \\
$\mathbf{2}$ & $47,63 \mathrm{a}$ & $64,85 \mathrm{a}$ & $20,94 \mathrm{a}$ & $22,40 \mathrm{a}$ & $6,32 \mathrm{a}$ \\
$\mathbf{7}$ & $53,97 \mathrm{a}$ & $19,10 \mathrm{a}$ & $18,18 \mathrm{a}$ & $5,32 \mathrm{a}$ \\
$\mathbf{1 2}$ & $48,11 \mathrm{a}$ & $44,94 \mathrm{~b}$ & $13,46 \mathrm{~b}$ & $15,16 \mathrm{a}$ & $4,14 \mathrm{~b}$
\end{tabular}

Followed values by equal letters in the same column do not differ with each other at $\mathrm{p}<0.05$ by the Scott-Knott test (1974). Source: Authors. 
It can be seen that the highest $\mathrm{N}$ dose used (12g), corresponding to treatment $\mathrm{T} 4$, provided values of 44,94 $\mathrm{g}$ of APFM, 13,46 g of RFM and 4,14 g of RDM, both statistically lower than those achieved in the other treatments.

The obtained values for APDM were higher than those found by Dias et al. (2020), which evaluated the cocoa seedlings development with organic fertilizer source supply, however, the RDM values were lower. This confirms that the nutrients supply from chemical sources through fertirrigation stimulates the aerial part rapid development, since these are readily available to plants, while the supply through organic sources especially favors the root development, mainly by the soil physical characteristics improvement.

The lower statistically average observed for fresh matter and dry matter from treatment $\mathrm{T} 4$ can be explained by the large consumption of carbohydrates by the plant, since the NH4+ assimilation in high amounts requires large amounts of carbohydrates (Souza \& Fernandes, 2018).

The results show a difference between the check and the treatment 4 for the evaluated parameters. These results partially corroborate with those found by Ramos et al. (2014), who did not found any difference for the roots dry mass of cacao seedlings subjected to different concentrations of $\mathrm{N}$ and $\mathrm{K}$.

In Figure 7, the quadratic regression graphics are presented that show the $\mathrm{N}$ doses influence on RL, APFM, RFM, APDM and RDM at 156 age days.

Figure 7: RL, APFM, RFM, APDM and RDM of cacao seedlings at 156 age days in $\mathrm{N}$ doses function.
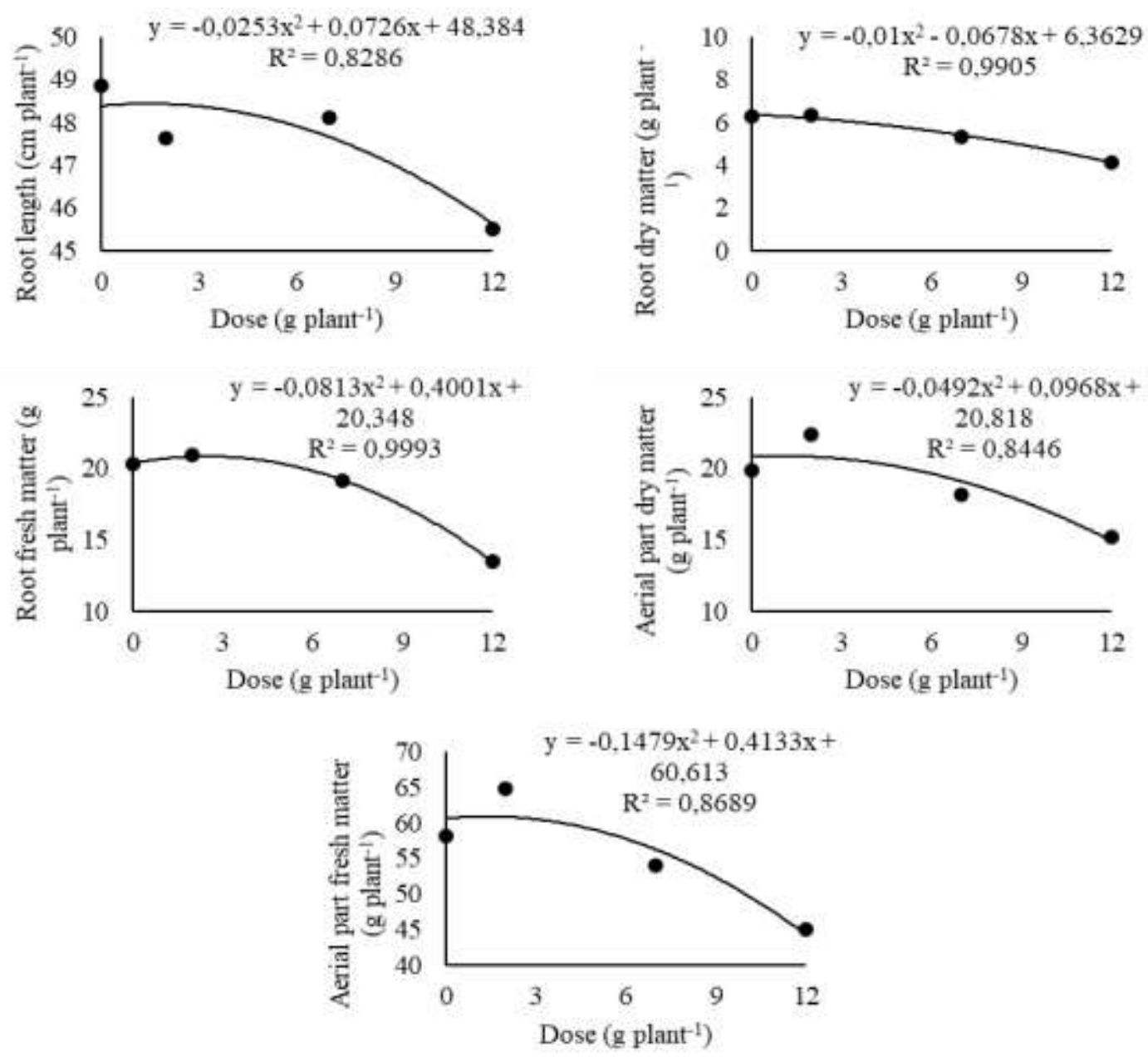

Source: Authors. 
It can be observed a decrease from the variables according to the doses increase. A possible explanation for this effect may be the fact that the urea on the soil rapidly transforms into ammonium $\left(\mathrm{NH}_{4}{ }^{+}\right)$, so that, in increasing concentrations, the seedlings might have absorbed a greater amount of $\mathrm{N}$ in the ammoniacal form, causing a toxic effect to the plant as seen by Silva et al. (2015) and Silva et al. (2014), when they evaluated the increasing $\mathrm{N}$ doses effect on the dry matter of guava and jackfruit seedlings, respectively.

The $\mathrm{N}$ absorption in excess in the ammoniacal form changes the water balance in plants, reducing the water flow from the roots to the plant aerial part, causing wilting (Souza \& Fernandes, 2018).

Although the APDM did not diverged between the treatments, the achieved results for this parameter were considerably higher than those found by Souza Júnior and Carmello (2012). This difference may be linked to the $\mathrm{N}$ higher amount used, however, other factors such as container, substrate and propagation form (sexual or asexual) may also have contributed to the observed differences.

\subsection{Nutrients accumulation}

The plant nutritional content from the leaf and root components presented oscillation in function of the treatments, showing antagonistic and synergistic interactions from $\mathrm{N}$ doses with some elements (Table 4).

Table 4: Nutritional chemical analysis from the root and leaf of cacao seedlings for different treatments.

\begin{tabular}{|c|c|c|c|c|c|c|c|c|c|c|c|}
\hline \multicolumn{12}{|c|}{ Root } \\
\hline \multicolumn{7}{|c|}{$\mathrm{g} \mathrm{kg}^{-1}$} & \multicolumn{5}{|c|}{$\mathrm{mg} \mathrm{kg}^{-1}$} \\
\hline Treatment & $\mathbf{N}$ & $\mathbf{P}$ & $\mathbf{K}$ & $\mathbf{C a}$ & Mg & $\mathbf{S}$ & $\mathbf{F e}$ & Zn & $\mathrm{Cu}$ & Mn & $\mathbf{B}$ \\
\hline T1 & 13,37 & 2,41 & 13,13 & 5,62 & 4,99 & 2,15 & 8919 & 30 & 19 & 393 & 9 \\
\hline $\mathbf{T} 2$ & 19,11 & 2,55 & 19,38 & 3,74 & 2,71 & 1,43 & 7345 & 34 & 36 & 754 & 11 \\
\hline T3 & 27,58 & 2,69 & 18,13 & 2,25 & 1,31 & 1,64 & 9983 & 33 & 62 & 1600 & 8 \\
\hline T4 & 58,7 & 2,22 & 13,75 & 2,17 & 0,88 & 1,43 & 11792 & 44 & 68 & 1316 & 8 \\
\hline \multicolumn{12}{|c|}{ Leaf } \\
\hline & \multicolumn{6}{|l|}{$\mathrm{g} \mathrm{kg}^{-1}$} & \multicolumn{5}{|c|}{$\mathrm{mg} \mathrm{kg}^{-1}$} \\
\hline Treatment & $\mathbf{N}$ & $\mathbf{P}$ & $\mathbf{K}$ & $\mathrm{Ca}$ & Mg & $\mathbf{S}$ & $\mathbf{F e}$ & Zn & $\mathrm{Cu}$ & Mn & B \\
\hline T1 & 17,01 & 2,16 & 14,38 & 9,23 & 6,83 & 1,74 & 237 & 30 & 11 & 1062 & 39 \\
\hline $\mathbf{T} 2$ & 24,64 & 2,55 & 15,63 & 9,62 & 2,45 & 1,43 & 297 & 40 & 8 & 3814 & 66 \\
\hline T3 & 26,18 & 2,92 & 16,25 & 8,53 & 1,75 & 1,37 & 263 & 25 & 7 & 5863 & 54 \\
\hline T4 & 32,41 & 2,69 & 16,88 & 9,36 & 1,58 & 1,3 & 287 & 21 & 7 & 4547 & 66 \\
\hline
\end{tabular}

Source: Authors.

As shown by the analysis, it is noted that there was the following relation of average concentration from macronutrients of $\mathrm{N}>\mathrm{K}>\mathrm{Ca}>\mathrm{Mg}>\mathrm{P}>\mathrm{S}$ for both leaves and root. The $\mathrm{N}, \mathrm{P}$ and $\mathrm{K}, \mathrm{Mg}, \mathrm{S}$ and $\mathrm{Zn}$ concentrations are similar between the root and leaf components, whereas $\mathrm{Ca}, \mathrm{Mn}$ and $\mathrm{B}$ had higher concentrations on the leaf than on the root, while Fe and $\mathrm{Cu}$ showed higher concentrations on the root than on the leaf. 
In Table 5, it is shown the leaf's nutritional levels classification according to its appropriate range for the cocoa crop, in accordance with Souza Júnior et al. (2012). As shown by the analysis, the check was the treatment that presented the highest normality in relation to the nutrients adequate levels, while the other treatments had changes in these levels.

It is noteworthy that all the treatments that used fertirrigation showed nutrients equal ranges, with the exception of $\mathrm{N}$, which was the only nutrient applied in different doses.

Table 5: Concentration degree of each element - high (H); average (A); low (L).

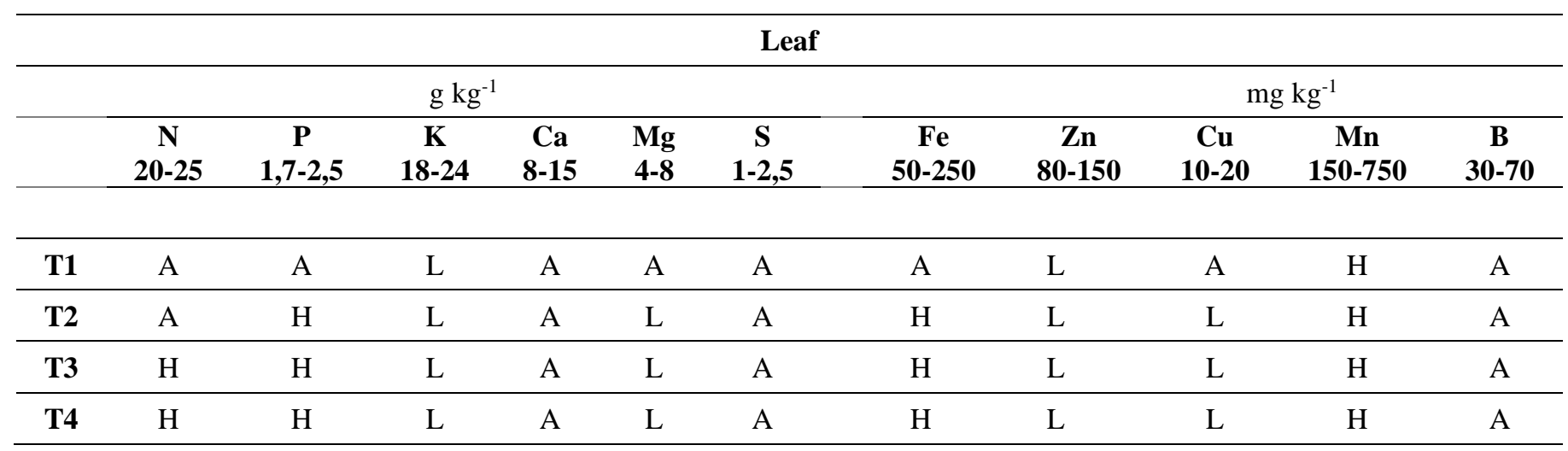

Source: Authors.

Analyzing each nutrient separately, it is observed that $\mathrm{N}$ had a marked accumulation in the root, as the doses increase. Despite of showing an increasing behavior on the leaves, it remained in average levels in the treatments $\mathrm{T} 1$ and $\mathrm{T} 2$, highlighting that the $2 \mathrm{~g}$ dose was not enough to leave its content above the adequate for the concentration normal range on the leaf tissue.

The $\mathrm{P}$ presented high considered values in the treatments with fertirrigation, possibly due to the phosphorus high concentrations present in the application solution. The $\mathrm{K}$ presented in low levels for all the treatments, however it was observed its increment as $\mathrm{N}$ doses were increased, possibly due to its important action in the $\mathrm{N}$ assimilation enzymes activation when $\mathrm{NH}_{4}{ }^{+}$is in toxic levels in the plant tissues (Souza \& Fernades, 2018), having its absorption also increased.

$\mathrm{Ca}, \mathrm{Mg}, \mathrm{Fe}$ and $\mathrm{Cu}$ were the most affected nutrients by the treatments. The $\mathrm{Ca}$, despite of presenting adequate values in relation to its content on the leaves, it was strongly affected in the root. The Ca decrease consequences in the roots can be seen visually (Figure 4) and also in the RFM and RDM values (Table 3), since this nutrient plays an important function on the cell wall and on the growth tissues. Souza and Fernandes (2018) report that the Ca absorption by the roots can be decreased by high concentrations of $\mathrm{K}^{+}, \mathrm{Mg}^{2+}$, and $\mathrm{N}_{-} \mathrm{NH}_{4}{ }^{+}$. These results corroborate with those obtained by Ramos et al. (2014), who also observed a decrease in $\mathrm{Ca}$ and $\mathrm{Mg}$ content with the increase from $\mathrm{K}$ content on the leaves.

The Mg levels were low in the treatments with fertirrigation. Differently what Ferreira et al. (2019) observed when obtaining $\mathrm{Mg}$ positive accumulation with the $\mathrm{N}$ doses increase in acerola seedlings, in this work the $\mathrm{Mg}$ nutrient content decreased as $\mathrm{N}$ doses were increased, being this behavior observed both in the root and on the leaves. This behavior may possibly be related to the $\mathrm{K}$ effect present in the nutritional solution or to a secondary effect of the $\mathrm{N}$ doses that promoted greater $\mathrm{K}$ absorption, causing the $\mathrm{Mg}$ content to reduce, similarly to what was observed by Ramos et al. (2014). The magnesium content reduction can be attributed to competitive absorption between these two elements (Viecelli, 2017). The Mg together with $\mathrm{N}$ are the only soil nutrients that are chlorophyll constituents, and its requirement in the cocoa crop is higher than that required by most crops (Souza \& Fernandes, 2018). 
The $\mathrm{Cu}$ values showed an average level in the control treatment, while for the other treatments it was observed a positive increment in the roots and a negative incremente on the leaves. Its deficiency on the leaves can be attributed by this element be one of the main nutrients affected by the $\mathrm{NH}_{4}{ }^{+}$presence (EMBRAPA, 2020). On the other hand, Fe, despite of a smaller difference between the treatments, it showed average levels only in the control treatment, while for the other treatments this level was high. It is likely that the high concentration of this nutrient in the roots be in function of the soil residues presence, being this behavior also observed for the Mn, which may be related to its abundance in most soils and association with Fe (Souza \& Fernandes, 2018).

\section{Conclusion}

The $\mathrm{N}$ supply via fertirrigation up to $2 \mathrm{~g}$ dose per plant promoted greater increments in height, collar diameter, fresh and dry root matter and aerial part.

Increasing $\mathrm{N}$ doses modify the nutritional absorption of some essential elements, altering their content in the plant tissue and promoting lower biometric parameters development.

\section{References}

Almeida, R. L. S. Da, Chaves, L. H. G., Bonomo, P., Almeida Júnior, R. L. S. Da, \& Fernandes, J. D. (2014) Produção do cacaueiro submetido a diferentes lâminas de irrigação e dose de nitrogênio. Revista Caatinga, 27(4), 171 -182.

Bezerra, J. L. S. Andrade Neto, R. C. Lunz, A. M. P., Araújo, C. S. \& Almeida, U. O. De. (2018) Fontes e doses de nitrogênio na produção de mudas de açaizeiro (Euterpe oleraceae Mart). Enciclopédia biosfera, Centro Científico Conhecer, 15(27), 541. 10.18677/EnciBio_2018A50

Coelho, E. F., Costa, E. L. Da, Borges, A. L., Andrade Neto, T. M. De, \& Pinto, J. M., (2010) Fertirrigação. Informe Agropecuário, Belo Horizonte, v.31, n.259, 58-70.

Dias, F. P. M., Paes, E. C. Jesus, I. C., Pereira, E. G., \& Nóbrega, J. C. A. De. (2020) Composto orgânico: Efeitos no desenvolvimento de mudas de cacaueiro. In: Congresso Brasileiro de Agroecologia, XI, 2019, São Cristóvão, Anais. São Cristóvão- Sergipe: ABA-Agroecologia, 15(2).

Empresa Brasileira De Pesquisa Agropecuária, Conceitos de fertilidade do solo e manejo adequado para as regiões tropicais. (2020) Ronquim, Carlos Cesar. 2.ed. - Campinas: Embrapa Territorial, 34 p.: il., (Boletim de Pesquisa e Desenvolvimento / Embrapa Territoria.

Empresa Brasileira De Pesquisa Agropecuária, Recomendações de adubação e calagem para o Estado do Pará (2007). Editores técnicos: Manuel da Silva Cravo, Ismael de Jesus MatosViégas, Edilson Carvalho Brasil. Embrapa Amazônia Oriental, 262p.

Ferreira, K. S., Rufini, J. C. M., Fagundes, M. C. P., Moreira, S. G., Ferreira, E. V. O. \& Barbosa, M. A. P. Crescimento e acúmulo de nutrientes em mudas de aceroleiras em função da aplicação de diferentes doses de nitrogênio e potássio (2019). Colloquium Agrariae, 15(2), 37-50. 10.5747/ca.2019.v15.n2.a283.

Gonçalves, E. O, Petri, G. M. Caldeira, M. V. W. D, Torezani, T, vSilva, A. G. Crescimento de mudas de Ateleia glazioviana em substratos contendo diferentes materiais orgânicos (2015). Floresta e Ambiente, 21(3), 339-348.

Instituto Brasileiro De Geografia E Estatística. Produção agrícola municipal - PAM. (2019).

Koppen, W. (1936). Das Geographische System der Klimate. In: Koppen, W., Geiger, R. eds. Handbuch der Klimatologie. Gebruider Borntraeger, Berlin. 44 .

Ramos, A., Sodre, G. A., Marrocos, P. C. L., \& Souza, J. E. J. De, Aplicação de nitrogênio e potássio via água de irrigação no crescimento de mudas clonais de cacaueiro. (2014). Agrotrópica 26(1): 27 - 34. Centro de Pesquisas do Cacau, Ilhéus, Bahia, Brasil.

Santos, A. C. Resíduo de cogumelo no crescimento e nutrição de mudas de cacau. (2019). 27f. Monografia (Bacharelado em Agronomia). Centro de Ciências Agrárias, Ambientais e Biológicas, Universidade Federal do Recôncavo da Bahia. Cruz das Almas - BA.

Silva, A. O. Da, Bassoi, L. H., Silva, D. J., \& Souza, D. R. M. Movimentação de nitrato e potássio em solo cultivado com videira fertirrigada no semiárido (2017). In: Congresso Brasileiro de Engenharia Agrícola, XLVI, 2017, Maceió. Anais. CONBEA.

Silva, C. P., Garcia, K. G. V., Tosta, M. S., Cunha, C. S. M., \& Nascimento, C. D. V. Adubação nitrogenada no crescimento inicial de mudas de jaqueira (2014). Enciclopédia Biosfera, 10(18), 174-180.

Silva, E. M. Da., Nobre, R. G., Souza, L. P. Pinheiro, F. W. A., \& Andrade, A. B. A. De. Efeito da adubação nitrogenada na formação de mudas de goiabeira irrigadas com águas salinas (2015). Revista Verde. Pombal - PB - Brasil, 10(4), 42 - 48, http://dx.doi.org/10.18378/rvads.v10i4.3735.

Sodré, G. A., Venturini, M. T., Ribeiro, D. O., \& Marrocos, P. C. L. Extrato da casca do fruto do cacaueiro como fertilizante potássico no crescimento de mudas de cacaueiro (2012). Revista brasileira de fruticultura. 34(3), 881-887. 
Research, Society and Development, v. 10, n. 11, e136101119396, 2021

(CC BY 4.0) | ISSN 2525-3409 | DOI: http://dx.doi.org/10.33448/rsd-v10i11.19396

Souza Júnior, J. O., \& Carmello, Q. A. C. De, Formas de adubação e doses de uréia para mudas clonais de cacau cultivadas em substrato (2012). Revista brasileira de ciência do solo.

Souza, C. A. S., Aguilar, M. A. G., \& Dias, L. A. S. Agrometeorologia dos Cultivos. O fator meteorológico na produção agrícola (2009) Instituto Nacional de Meteorologia (INMET). Brasília, cap. 20, p. 333.

Souza, S. R. \& Fernandes, M. S., Nitrogênio. In: Nutrição Mineral de Plantas (2018). (2a ed.), 670. SBCS.

Taiz, L., \& Zeiger, E. Fisiologia vegetal: Nutrição Mineral (2017) (6a ed.), 888p.

Trevisan, M. H., Silva, S. A. S. Da., \& Silva, R. O. Da, Development of Raphanus sativus L. under different water depths and organic fertilizer sources (2020). Amazonian jornal of plant research. 10.26545.

Viecelli, C. A. Guia de deficiências nutricionais em plantas (2017). - Toledo, PR:PUCPR Campus Toledo / Grupo Marista, ASSOESTE. 